\title{
ТРАНСФОРМАЦИЯ ТРАГИЧЕСКОГО: РУССКАЯ КЛАССИКА В МИРОВОЗЗРЕНЧЕСКИХ КОНЦЕПЦИЯХ УКРАИНСКОГО МОДЕРНИЗМА
}

\author{
TRANSFORMATION OF TRAGEDY: RUSSIAN CLASSICS ACCORDING \\ IN THE PHILOSOPHICAL CONCEPTS OF UKRAINIAN MODERNISM
}

\author{
ГАЛИНА КОРБИЧ
}

\begin{abstract}
This article describes the attitude of Ukrainian authors of the late 19th and early 20th century (Ivan Franko, Mykola Yevshan, Mykyta Sryblyans'kyi and others) toward the manifestations of tragedy in Russian literature of the 19th century. The primary focus is on Fyodor Dostoevsky's anthropological discoveries, Nikolai Gogol's existentialism and Leo Tolstoy's psychologism. The ideas of these writers were considered conformable to the perception of the fin-de-siècle world with its tragic background and helped Ukrainian writers form their own philosophical and aesthetic views. Russian classics were studied with regard to realistic aesthetics and treated similarly to the classics of antiquity, i.e. as an unchanging value.
\end{abstract}

Halina Korbicz, Uniwersytet im. Adama Mickiewicz w Poznaniu, Poznań - Polska.

Трагическое как философская и эстетическая категория в искусстве является одной из заметных составных в культуре модернизма, особенно на раннем его этапе, каким принято считать рубеж XIX и XX веков. Хотя понятие „трагическое” характеризует признаки, остававшиеся неизменными в разные культурно-исторические периоды и обусловленными особенностями развития того или иного общества, именно в конце XIX - начале XX ст. смысл этого понятия выходит за пределы традиционной нормативности, активизируется, заостряется, приобретает новые семантические значения. В нем драматично отражался кризисный характер переходной эпохи, выразившийся в утрате веры в человеческий разум, в разочаровании и пессимизме. Пролог к новой культурно-мировоззренческой ориентации, заложившей фундамент „философии жизни" (учения Артура Шопенгауэра, Фридриха Ницше, Вильгельма Дильтея, Анри Бергсона и других мыслителей), дают музыкальные драмы Рихарда Вагнера и идеи Ницше. Первая книга немецкого философа неслучайно называется Рождение трагедии, или Элинство и пессимизм (1872). В ней формируется главная проблема всей жизни и философии Нищше: как, каким путем создать такую 
культуру, подчиняясь которой человек мог бы облагородить свой внутренний мир и воспитать себя самого. Способ решения проблемы во многом заключается в символическом требовании „возрождения трагедии" и в самой идее трагического познания, в книге также звучит надежда на возрождение трагического века с его дионисическим искусством, ставшим своеобразным символом жизненности. На рубеже веков возрождается и модернизируется классическая трагедия с античными сюжетами, драматурги обращаются к интертекстуальным возможностям, в частности к реминисценциям „вечных образов” и мотивов (Гуго фон Гофмансталь, Герхард Гауптман, Вячеслав Иванов, Иннокентий Анненский и др.), к их стилизации и адаптации к художественно-эстетическим требованиям нового времени. Кризис эмпирического логоцентризма обозначился в символистской драме Мориса Метерлинка, а трагические мотивы лишенной духовности жизни, несовместимой со свободной самореализацией личности, доминируют в драматических произведениях Генрика Ибсена и Антона Чехова.

В украинской литературе этого времени также прослеживается сильный античный контекст. Путем интерпретаций, трансформаций, явного и скрытого восприятия входят античные сюжеты, герои, мифы и мифологемы в художественный мир писателей: Людмилы Старицкой-Черняховской (Сапфо), Ольги Кобылянской (Ниоба), Модеста Левицкого (Ниобея), Владимира Самийленко (Герострат, Гея), а также поэтов Александра Олеся, Василия Пачовского, Петра Карманского и многих других. Особенно ярким воплощением преобразующегося жанра трагедии и приобретенных им новых смысловых признаков стало творчество Леси Украинки. В целом ряде драматических произведений (Руфин и Присииила, Ифигения в Тавриде, Кассандра, Орфеево чудо и других) поэтесса использует античные образы и мотивы. Сохраняя свое символическое значение, они в то же время наполняются конкретным историческим содержанием, в контексте которого, однако, легко прочитываются социокультурные особенности и национальная проблематика тогдашней украинской жизни. Отношение же самой поэтессы к трагическому подытожил в свое время известный критик и литературовед Мыхайло Драй-Хмара, отмечая, что в Лесиных драмах даже „стремление к подвигу [...] имеет трагический оттенок. В этом отношении она занимает одну позицию с Ибсеном, Метерлинком и Роменом Ролланом"1. Таким образом, в отличие от европейского классицизма XVII-XVIII веков, на рубеже XIX и XX столетий античность воспринимали не столько как идеал культуры или эталон стиля,

${ }^{1}$ М. Д р а й - Х м а р а, Леся Українка. Життя і творчість, [в:] его же, Літературно-наукова спадщина, Київ 2002, с. 105. 
сколько как материал для ассоциативных вариаций социокультурных и эстетических проблем своего времениㄹ․ Из античной трагедии и мифологических представлений, от которых трагедия собственно берет свое начало, формируются тенденции, в целом примечательные для эпохи fin de siécle: не в эпике Гомера и не в эпопее Вергилия видели поэты и писатели простор для творческого освоения, а именно в трагедии с ее драматическим напряжением, остротой ситуаций, героическими характерами.

Ранний украинский модернизм находился в сфере влияния ведущих идей своего времени. Он совокупно ассимилировал философские и эстетические взгляды популярных во второй половине XIX - начале XX ст. авторов, освоил экспериментальные художественные формы, вырабатывая собственную речь, способную выразить украинскую культурную индивидуальность. В амбициозном стремлении создать новую модель украинской культуры, полностью оторванную от ее прошлого развития, многие украинские деятели (писатели, критики, культурологи) старались использовать своего рода „элементы” как культуры западного типа, так и русской литературы. Причем если в обращении к Европе их преимущественно интересовали достижения нового времени, то в отношении России внимание приковывало русское литературное наследие XIX века. В украинской трактовке оно выводилось за рамки реалистической эстетики и становилось созвучным современному миропониманию.

Действительным реализмом, - отмечал один из лидеров украинского модернизма Мыкыта Сриблянский, - является не приём в писании, а мировоззрение. Писание реалистическое - это только проявление реалистического понимания жизни. Писатели в русской литературе реалистами были оттого, что главными основами их мышления, их мировоззрения была жизнь во всех ее проявления $x^{3}$.

Русская классика воспринималась подобно античности: в категории ценности, неподвластной времени. Антропоцентризм - определяющая черта античности - был одинаково характерен и для русской литературы. Сосредоточенность на масштабных проблемах духовной жизни, утверждение ценности человека в социальном мире и вообще „переключение" внимания от социума на внутренний мир человека, которое совершается в произведениях Льва Толстого, Федора Достоевского, Антона Чехова и других писателей, закладывалось в основу украинских модернистских взглядов на назначение литературы и искусства.

2 См.: А.Ф. Л о с е в, Очерки античного символизма и мифологии, Москва 1993, с. 25.

${ }^{3}$ M. С р і б л я н с ь к и й, Pro domo sua. Haша література, "Українська хата" 1909, № 7-8, c. 421. 
Модернизм же выдвигает понятие человека как ключевую основу философствования. В кругах украинской творческой молодежи зрело убеждение, что критический реализм раскрыл трагический распад личности и общества, а источником трагического являются специфические общественные противоречия. Неслучайно возникает внимание к произведениям Достоевского, к его антропологическим открытиям. Присущее творчеству писателя душевное напряжение, соединенное с предчувствием неизбежной катастрофы, кризис человеческого духа звучали не столько как эпический дискурс, сколько как действия и речевые выражения персонажей, склонных постигать за свободой этическую природу человека, принимать жизненные события как трагические потрясения, что ведут к настоящему бытию.

И страшные видения Достоевского, и пессимизм всей русской литературы не угнетают человека теми страшными картинами. Они все слишком искренние, и слишком любят человека. Убивая голой правдой жизни и души иллюзии, они словно очищают душу, как очищает гроза воздух. Я не могу даже видеть тут скептицизма. Пускай, что тут изображена безысходность, безнадежность, фатализм жизни, но чистота чувствований, невинность сердца и души человеческой таки остаются, не замаранные ничем, даже трудной школой жизни. Так вот, все высокие чувства любви, дружбы, посвящения и труда остаются непоколебимыми, благородные порывы и стремления не угасают в душе. Есть ценности, от которых, помимо всего, нельзя отречься и которые дают силу выдержать напор обыденности на жизнь и побороться с фатализмом ${ }^{4}$.

Так высказывался о русских реалистах один из наиболее последовательных приверженцев модернизма, молодой украинский критик Мыкола Евшан. Об универсальности реализма Достоевского упоминал великий украинский писатель Иван Франко. Он прямо противопоставлял русского писателя западноевропейским авторам, подчеркивая духовность Достоевского, основанную на определяющем для русских писателей внимании к человеку, - в противовес Западу, который все более поддавался прагматизму (примером служило, в частности, творчество Эмиля Золя). Материальная среда у Достоевского, по мнению Франко, очертана выразительно, но сжато, а в центре повествования находятся персонажи и их внутренний мир.

Люди стоят на первом плане, а их душевное состояние является той атмосферой, что пронизывает, заполняет всю повесть, передается читателю, мучит и потрясает его 5 .

${ }^{4}$ М. $С$ в ш а н, Герман Банг, артист і чоловік. Психологічна студія, [в:] его же, Критика. Літературознавство. Естетика, Київ 1998, с. 415-416.

${ }^{5}$ I. Ф р а н к о, Еміль Золя, його життя і писання, [в:] его же, Зібрання творів у 50-ти томах, т. 31, Київ 1981, с. 305. 
Верно усматривалось неизбежное влияние Достоевского на мировую литературу, на каждого крупного писателя, и безошибочно угадывалось, что дорога, по которой пойдут последователи русского прозаика, ведет к модернизму. Несмотря на то что в большинстве произведений русских реалистов вскрыты глубочайшие конфликты действительности, носящие преимущественно острый кризисный характер, они, подобно изначальным положениям трагедии, наделялись катарсическими свойствами, порождали чувство „очищения искусством”. В оценке романов Достоевского и Толстого, рассказов Чехова, повестей Владимира Короленко содержится не сопереживание с героями произведений, а именно эстетическое переживание, свойственная трагедии встреча сознаний читателя и автора, „ответ на чужую духовность” (по Михаилу Бахтину). Такой подход влиял на формирование украинского модернизма. Его особенностью как мировоззренческого и духовного феномена является преодоление упадочнических настроений Запада и направление своей энергии на созидание нового, модерного искусства. Недаром ранний украинский модернизм принято не соотносить с понятием fin de siècle, а называть commencement de siècle, что должно символизировать начало, утверждать новое. И в прямом смысле окончательное становление модернизма в Украине, его зрелость и разностороннее развитие утверждается в начале XX столетия.

Характерно, что высокая оценка русской литературы XIX века, полная акцептация ее пригодности для философско-эстетических опор нового времени, и даже намерение использовать ее открытия для украинского культурного проекта - такая установка идет вразрез с трактовкой родной культуры. Украинские авторы (Мыкола Евшан, Мыкыта Сриблянский, Андрий Товкачевский, Гнат Хоткевич и многие другие) объявили настоящую войну украинским народникам с их установкой на доминирование реалистических принципов в искусстве. В духе антипозитивистских настроений эпохи осуществлялось полное отрицание народническо-реалистической идеологии как устаревшей, ограниченной и отсталой. Главный конфликт в украинской общественно-культурной жизни, как верно считала Соломия Павлычко, „имел место между философиею народничества, в пределах которой сформировались все художественные традиции XIX столетия, и модернизмом - новыми эстетическими и политическими принципами XX"6.

Обращение к творчеству русских писателей вносит корректив во взгляды модернистов на основопологающие величины нового искусства, обнаруживая тем самым самостоятельность исканий украинских адептов современности, их нежелание идти априорным путем. Так,

6 С. П а в л и ч к о, Дискурс модернізму в украӥнській літературі, Київ 1999, с. 19. 
в частности, видоизменяется понятие модернистских противоречий между высоким назначением искусства и тривиальностью повседневной жизни. Это свойственное модернистам всех стран противопоставление или, вернее, отрицание значимости обыденной жизни для искусства породило желание бегства (часто в неизвестное, даже в нирвану, лишь бы подальше от однообразия) ${ }^{7}$. В украинской же модерной ситуации такая ориентация, ставшая традиционной в европейском модернизме, как раз наоборот - оборачивается вниманием к повседневности. Сознание неизбежности существования человека в реалиях будней, в их приземленных формах рождает, с одной стороны, принятие тривиальной действительности как необходимости, с другой же - осознание „серой и будничной жизни” как драмы, как трагедии „ломки крыльев" (Мыкола Евшан). Тенденции изображать действительность в объектированных формах: „писать апологию людей, слабых от будничной жизни, людей, которые живут украдкой", - такой тенденции должен противодействовать механизм высокой литературы. А именно - „поэтический порыв от прозы жизни”. К такому выводу приходит Евшан, вникая в творчество Николая Гоголя. По мнению критика, Гоголь не только верен реальности, величие его не только в том, что он ценил „правду жизни”, творчество Гоголя стало классическим образцом именно по причине умения писателя преображать „низкое” в „высокое” и во внешне нейтральном показать трагизм экзистенции. „На той страшной повседневности построил такую сильную, высокую поэзию, извлек из нее столько кровавой лирики и плача"8. Национальные корни такого подхода проросли, как считает Евшан, от Гоголя к Тургеневу, Достоевскому, Чехову, творчество которых также формировалось из наблюдений за повседневной жизнью. Тот факт, что русские реалисты сумели возвысить серые будни в ранг высокого искусства, считался не только их художественно-эстетическим достижением, но и настоящим моральным подвигом. Наблюдениям за „проживанием жизни” как „смертельного хронотопа” (Франц Кафка) противопоставляется жизнь в искусстве как бунт против застоя, творчество против бездеятельности.

Таким образом, эстетизм - центральная установка модернизма - уточняется в украинской литературно-критической мысли простой жизнью и в результате такой трактовки становится разветвленной парадигмой со многими нюансами. Поиск высоких принципов в искусстве привел украинских адептов модернизма к осознанности ценности

${ }_{7}$ Cм.: M. P o d r a z a - K w i a t k o w s k a, Wolność i transcendencja. Studia i eseje o Młodej Polsce, Kraków 2001, c. 92.

8 М. С в ш а н, Герман Банг..., указ. соч., с. 409. 
опыта реалистов. За видимой прозаичностью реалистических произведений открывалась экзистенционная и философская глубина, обусловленная возможностью преобразить закрепленное в литературе понятие „прозы жизни”, как проявление обыденности, в поэзию - сферу влияния элитарной культуры, а воплощенную в слове „правду жизни” (так преимущественно определяли реалистическую литературу) - в категорию универсальной эстетической ценности. В зависимости художественной системы реализма от объективной действительности, в творческом наполнении содержательного и художественного уровней этой системы распознавали украинские авторы подсказку для своих сомнений. По мере созревания украинской модернистской формации смягчалась эпатажность в выступлениях ее создателей, в том числе принципиальное отвержение ими действительности как объекта, лишенного духовных мотивов, преображалось в поиск эстетических сущностей, который осуществлялся в результате внимания к противоположностям.

Художественный модернизм возник в одно время с психоанализом и развивался модернизм под его прямым и непрямым влиянием. Таким образом, психоанализ, оформленный открытиями Зигмунда Фрейда, заложил методологию для модернизма9. Это видно во всем комплексе литературно-критических работ украинских авторов конца XIX - нач. XX века. Как критикам молодого поколения, так и авторам среднего присущи попытки заглянуть в психологию писателя, поставить акцент на психологию творчества. Творчество для них - это отражение души или психики художника слова, а искусство - отдельный мир, отличный от мира жизни. Интерес к психологии скорее всего общий, даже экзистенциональный - с точки зрения универсального трагизма судьбы творческой личности, универсальности ее душевных конфликтов. Имманентной внутренней чертой художника, его опознавальным знаком становится своеобразная „творческая тоска” или тревога, что проявляется во внутреннем раздвоении или даже фатализме. Такой подход совпадает с понятием трагического как категории в искусстве, характеризующейся возникновением страданий и переживаний героев произведений в результате актов их свободной воли или предначертаний судьбы ${ }^{10}$. Для критика же аналогом героев произведений становились их авторы - писатели, с которыми критик был связан эмоционально и которые наиболее его интересовали.

Сложным и противоречивым казалось для ведущих украинских авторов жизнетворчество Льва Толстого. Двойственность его творче-

${ }_{9}^{9}$ Н.В. 3 б о р о в с ь к а, Психоаналіз і літературознавство, Київ 2003, с. 95.

${ }_{10}$ См.: Трагедия (жанр), [электронный ресурс:] http://ru.wikipedia.org/wiki/Трагедия _(жанр) (15.11.2012). 
ской натуры - великого писателя, с одной стороны, и религиозного мыслителя и проповедника новых моральных принципов жизни, с другой - расценивалась как драматический переход от первого ко второму, как факт, трагический не только для самого Толстого, но и для всей русской, а то и мировой литературы. Этот переход воспринимался как внутреннее раздвоение писателя и трактовался в качестве психологического конфликта. В результате перелома не совершалось катарсисное перерождение личности, что обычно происходит с творческими индивидуальностями, а возникали масштабные губительные последствия, которые к тому же имели прямое отношение к событиям внешнего плана - потеря великого писателя для художественного творчества. Так, по мнению Евшана, Толстой - „раб опинии”: он пожертвовал искусством как естественным проявлением своей творческой индивидуальности в пользу накинутым извне идеям общественных преобразований, а целью своей жизни сделал служение интересам общества. В результате, как считал критик, свершилось „самоумерщвление и самоубийство художественного гения"11. Более спокойно воспринимал творческое раздвоение Толстого Мыхайло Грушевский. В отличие от Евшана он усматривал не резкий переход, а определенную эволюцию в творческом пути писателя. „Морализаторское течение", как считал Грушевский, начало явно пробиваться уже в первом периоде творчества Толстого (к нему критик отнес роман Анна Каренина). Оно развивалось дальше (писатель „ставит в своих артистических произведениях проблему нравственности человека”) вплоть до самопроявления - сознательной деятельности в качестве реформатора религиозных и нравственных устоев жизни ${ }^{12}$. Так в интерпретации Грушевского формировалась система этических взглядов Толстого в художественном творчестве, - в отличие от Евшана, в понимании которого она складывается в мировоззренческой сфере, то есть отдельно от художественного творчества и даже является его антитезисом. Прямолинейно по поводу преображения во внутреннем мире писателя высказывался и Франко, считая, что уже в его ранних произведениях „поэт-мистик и метафизик-теолог соревнуются между собой"13. Критик аналитически подходил к душевному состоянию творческой личности, прекрасно понимая, что „Переход из одного лагеря в другой у Толстого не обошелся без глубокой внутренней борьбы, без сомнений и разочарований". Свидетельством для Франко в первую очередь

${ }_{11}$ М. Є в ш а н, Леъ Толстой (1828-1910), [в:] его же, Критика. Літературознавство..., указ. соч., с. 296.

12 М. Г р у ш е в с ь к и й, Юбилей Льъа Толстого, „Літературно-науковий вістник" 1908, т. 43, кн. 9, с. 535.

13 I. Ф р а н к о, Леъ Толстой, [в:] его же, Зібрання творів..., указ. соч., т. 28, с. 229. 
являются новеллы Толстого Три смерти, Алъберт и Поликушка, „овеянные тяжелым настроением меланхолии" 14 . Ценя Толстого как глубокого знатока жизни и человеческих взаимоотношений - „атлета в сфере духа", Франко в то же время поддает сомнению целесообразность его реформаторских исканий, в особенности убежденность автора Войны и мира в неизбывном зле, приносимом людям цивилизацией. И подобно своим собратиям по перу, Франко видит раздвоенность натуры Толстого, „которая со временем сильно подорвала его художественное творчество и привела его на путь, что не имеет ничего общего с его писательским призванием"15. С именем Толстого связаны, таким образом, напряженные коллизии, присущие преимущественно трагедии, и развязка в судьбе писателя, подобно ей, происходит весьма драматически. В контексте литературно-критических статей Евшана, Грушевского, Франко, затрагивающих проблемы творческих исканий Толстого, содержится мысль, что метафизическое мотивирование античной трагедии уступает место развитой психологической мотивировке, выдвигая на первый план анализ человеческих чувств и страстей в их конфликте с моральным императивом.

Наблюдения за сменой деятельности Толстого, воспринятые в ключе глубоких психологических противостояний, утверждали украинских критиков рубежа столетий в правильном выборе своих позиций - принятии эстетических предпочтений и философских концепций, выражающих самоценность художественного творчества, независимость искусства от общественных требований, воспитательных задач, политики и т.п. Внимание же к проявлениям трагического в русской классике помогало формировать собственные мировоззренческие убеждения, основанные на углубленном познании человека, общества, искусства. Искусство оказывалось долговечнее трагедии, а вместе с искусством - и художник. Потому что художник выступает в роли индивидуума, в роли героя своего времени (как это воспринималось по отношению к Гоголю, Достоевскому, Толстому). Его мироощущение в большей степени предопределяется динамикой, логикой и законами писательского творчества, чем его реальным историческим опытом. Долг художника перед обществом - выразить это мироощущение, предложить его читателям. Если искусство чему-то и учит человека, так это - уподобиться искусству, а не другим людям. Такое отношение к искусству - как примату над действительностью - старались привить своим читателям украинские авторы конца XIX - нач. XX веков. Обращение к русской классике помогало в достижении этой цели.

\footnotetext{
14 Там же, с. 235.

15 Там же, с. 233.
} 
